\title{
ВИКОРИСТАННЯ ТЕХНОЛОГІЇ DАТА MINING ДЛЯ З'ЯСУВАННЯ СУДОВО-МЕДИЧНИХ ЕКСПЕРТНИХ ОСОБЛИВОСТЕЙ НЕНАЛЕЖНОЇ МЕДИЧНОЇ ДОПОМОГИ
}

\author{
В. П. Марценюк, В. В. Франчук', \\ А. С. Сверстюк ${ }^{1}$, О. В. Франчук ${ }^{2}$ \\ Університет Бєльсько-Бяли, Республіка Польща \\ ${ }^{1}$ ДВНЗ «Тернопільський державний медичний університет \\ імені І. Я. Горбачевського МОЗ України» \\ ${ }^{2}$ Національний університет «Києво-Могилянська академія»
}

\begin{abstract}
У роботі представлені можливості технології штучного інтелекту Data Mining, зокрема методу індукції дерев рішень, для вирішення спеціальних питань під час судово-медичної експертизи кримінальних проваджень, відкритих проти лікарів у випадках неналежного надання медичної допомоги. На підставі отриманих результатів, обґрунтованих автоматизованою математичною програмою інтелектуальної обробки бази даних, встановлені конкретні судово-медичні експертні особливості неналежної медичної допомоги на прикладі кримінальних справ, порушених проти лікарів-терапевтів.
\end{abstract}

Ключові слова: судово-медична експертиза, неналежне надання медичної допомоги, лікарські справи, дерево рішень.

\section{DATA MINING TECHNOLOGY USING FOR DETERMINATION OF FORENSIC- MEDICAL PECULIARITIES OF INAPPROPRIATE MEDICAL CARE}

V. P. Martsenyuk, V. V. Franchuk ${ }^{1}$, A. S. Sverstuk ${ }^{1}$, O. V. Franchuk ${ }^{2}$ University of Bielsko-Biala, the Republic of Poland

${ }^{1}$ SHEE I. Horbachevsky Ternopil State Medical University of the Ministry of Health of Ukraine ${ }^{2}$ National University of «Kyiv-Mohyla Academy»

The paper presents Data Mining technology, in particular the method of induction of decision trees, for solving of special issues during forensic medical expertise in cases of medical malpractice. Based on the obtained results with using of the automated mathematical program of intellectual processing of the database, specific forensic expert peculiarities of inappropriate medical care were established. Presented research was performed on the example of medical malpractice litigation in internal medicine practice.

Key words: forensic medical examination, inappropriate medical care, medical malpractice litigation, decision tree. 


\title{
ИСПОЛЬЗОВАНИЕ ТЕХНОЛОГИИ DАТА MINING ДЛЯ УСТАНОВЛЕНИЯ СУДЕБНО-МЕДИЦИНСКИХ ЭКСПЕРТНЫХ ОСОБЕННОСТЕЙ НЕНАДЛЕЖАЩЕЙ МЕДИЦИНСКОЙ ПОМОЩИ
}

\author{
В. П. Марценюк, В. В. Франчук ${ }^{1}$, \\ А. С. Сверстюк ${ }^{1}$, О. В. Франчук ${ }^{2}$ \\ Университет Бельско-Бялы, Республика Польша

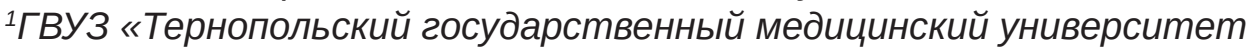 \\ имени И. Я. Горбачевского МЗ Украины» \\ ${ }^{2}$ Национальный университет «Киево-Могилянская академия»
}

\begin{abstract}
В работе представлены возможности технологии искусственного интеллекта Data Mining, в частности метода индукции деревьев решений, для решения специальных вопросов во время судебно-медицинской экспертизы уголовных дел, возбуждённых против врачей в случаях ненадлежащего оказания медицинской помощи. На основании полученных результатов, обоснованных автоматизированной математической программой интеллектуальной обработки базы данных, установлены конкретные судебно-медицинские экспертные особенности ненадлежащей медицинской помощи на примере уголовных дел, возбужденных против врачей-терапевтов.
\end{abstract}

Ключевые слова: судебно-медицинская экспертиза, ненадлежащее оказание медицинской помощи, врачебные дела, дерево решений.

Вступ. Медична допомога, що надається в закладах охорони здоров'я, з огляду на велику кількість як об’єктивних, так і суб’єктивних причин не завжди завершується сприятливо та може призвести до негативних для пацієнтів наслідків. У таких випадках виникають скарги громадян на неналежне виконання медичними працівниками своїх професійних обов'язків, що стає підставою для відкриття проти лікарів кримінальних проваджень. Під час розслідування таких «лікарських справ», відповідно до діючих законодавчих вимог обов'язково призначається судово-медична експертиза, що повинна з' ясувати - чи була медична допомога надана належним чином, чи правильно виконували свої професійні обов’язки медичні працівники, чи пов' язані шкідливі наслідки з певними діяннями медичного персоналу тощо. [2]. I хоча більшість таких справ викликана неумисними (тобто незлочинними) діями медиків, а їхніми професійними помилками на тлі добросовісного виконання власних посадових обов’ язків [8], справи про притягнення лікарів до відповідальності набувають гучного резонансу та вкрай негативно оцінюються суспільством.

Для того аби запобігти можливій шкоді внаслідок неналежного лікарювання, необхідно, щоб лікарі знали про причини власних помилок, умови їх виникнення і можливі наслідки. Адже таке знання дозволяє медичному працівнику передбачати можливі упущення у своїй професійній діяльності, що, зрештою, дозволить значно знизити ризик виникнення ятрогенних ускладнень у клінічній роботі [1].

Вирішення цієї проблеми тісно пов’язано з судовою медициною, одним із головних завдань якої $€$ профілактика помилок під час надання медичної допомоги, що вирішується шляхом аналізу судовомедичних експертних висновків у випадках лікарських справ із узагальненням та систематизацією виявлених недоліків [6].

Традиційні підходи до аналізу недоліків медичної допомоги грунтуються на загально відомих статистичних методах обробки даних, які надають звичайні відносні чи абсолютні цифрові величини стосовно загальної кількості тих чи інших дефектів медичної допомоги чи розповсюдженості їхніх видів серед представників конкретних лікарських спеціальностей тощо. Однак в умовах неочевидності, складності і багатофакторності системи, яка підлягає дослідженню, коли серед великого масиву розрізнених даних необхідно виявити силу інформаційних взаємозв’язків між цими даними [4], методів звичайної статистичної обробки стає недостатньо [5, 7]. За таких обставин для вирішення завдань класифікації та прогнозування в медицині останнім часом розпочато застосування технологій штучного інтелекту, наприклад технології обробки і аналізу даних Data Mining, зокрема найбільш популярного її методу - побудови дерев рішень (decision trees) [3, 9, 10]. Заразом, незважаючи на використання цього методу для запитів клінічної медицини, технології пошуку прихованих знань чи 
взаємозв’ язків у великому обсязі первинних даних для запитів судово-медичної експертної практики ще донедавна не вивчались і не застосовувались.

Мета дослідження: з'ясувати можливості методу індукції дерев рішень для програмної реалізації у системі прийняття рішень експертними комісіями під час судово-медичної експертизи у випадках відкриття кримінальних проваджень з приводу неналежного надання медичної допомоги.

Матеріали та методи дослідження. Досліджено матеріали судово-слідчих справ (так звані лікарські справи), порушених у випадках неналежного виконання професійних обов'язків медичними працівниками 10 областей України: Тернопільської, Хмельницької, Житомирської, Волинської, Чернівецької, Вінницької, Львівської, Рівненської, Івано-Франківської та Чернігівської. Загалом вивчено 350 таких справ, за кожною з яких правоохоронними органами були призначені комісійні або комплексні судово-медичні експертизи, які були виконані протягом 2007-2016 років фахівцям Тернопільського, Чернівецького та Житомирського обласних бюро судово-медичної експертизи. Для кожної з таких справ вивчали дані стосовно представників конкретних лікарських спеціальностей, проти яких було призначено розслідування; видів помилок; якісних їх особливостей; етапів медичної допомоги, на яких були допущені дефекти; причин, що сприяли недоліку; наявності порушень стандартів медичної допомоги; наявність прямого причинно-наслідкового зв’язку між неналежними діями медичного персоналу і шкідливим наслідком. Було виокремлено 70 різноманітних показників для кожної лікарської справи, відтак загалом вивчено 24500 даних.

Результати та їх обговорення. Обгрунтовуючи теоретичні основи методу індукції дерева рішень, сформулюємо задачу індукції дерева рішень. Маємо множину D, що містить $\mathrm{N}$ наборів навчальних даних. При цьому кожен і-й набір $\left(A_{1}^{i}, A_{2}^{i}, \ldots, A_{p}^{i}, C^{i}\right)$ складається $з$ вхідних даних атрибутів $A_{1}, \ldots, A_{p}$ та вихідних даних - атрибуту класу С. Атрибути $A_{1}, \ldots, A_{p}$ можуть приймати як чисельні, так і категоріальні значення. Атрибут класу С приймає одне з К дискретних значень: $C \in\{1, \ldots, K\}$. Метою $є$ прогнозування деревом рішень значення атрибуту класу С на основі значень атрибутів $A_{1}, \ldots, A_{p}$. При цьому слід максимізувати точність прогнозування атрибуту класу, а саме $P\{C=c\}$, на термінальних вузлах для довільного $c \in\{1, \ldots, K\}$. Алгоритми індукції дерев рішень автоматично розбивають на вузлах значення чисельних атрибутів $A_{i}$ на два інтервали: $A_{i} \leq x_{i}$ та $A_{i}>x_{i}$, а категоріальних атрибутів $A_{j}-$ на дві підмножини: $A_{j} \in S_{j}, A_{j} \notin S_{j}$. Розбиття чисельних атрибутів грунтується зазвичай на мірах на основі ентропії, або індексі Джині [11]. Процес розбиття рекурсивно повторюється доти, поки не спостерігатиметься покращення точності прогнозування. Останній крок включає вилучення вузлів для уникнення оверфітингу моделі. В результаті повинні отримати множину правил, що йдуть від кореня до кожного термінального вузла, містять нерівності для чисельних атрибутів та умови включення для категоріальних атрибутів.

Алгоритм методу індукції дерева рішень.

За основу взято таку рекурсивну процедуру роботи [11].

\section{Генерація дерева рішень.}

Вхідні дані: $D$ - множина навчальних наборів даних $\left(A_{1}^{i}, A_{2}^{i}, \ldots, A_{p}^{i}, C^{i}\right)$.

Вихідні дані: дерево рішень.

Алгоритм методу індукції дерева рішень:

1. Створити вузол $N$.

2. Якщо усі набори в $D$ належать до спільного класу $C$, тоді повернути вузол $N$ як листок із назвою класу $C$.

3. Якщо список атрибутів (а отже і $D$ ) є порожнім, тоді повернути вузол $N$ як листок із назвою найпоширенішого класу в $D$.

4. Застосувати алгоритм відбору атрибуту із списку атрибутів і для множини $D$ з метою відшукання «найкращого» атрибуту поділу.

5. Вилучити атрибут поділу із списку атрибутів.

6. Для кожної умови поділу ј для атрибуту поділу розглянемо $D_{j}$ - множину наборів з $D$, що задовольняють умову поділу $j$.

7. Якщо $D_{j}$ - порожня, тоді приєднати до вузла $N$ листок під заголовком найпоширенішого класу в $D_{j}$, інакше - приєднати до $N$ вузол, що повертається рекурсивним викликом методу генерації дерева рішень з вхідними даними $D_{j}$, та список атрибутів.

8. Кінець циклу кроку 6.

9. Повернути вузол $N$.

\section{Алгоритму відбору атрибуту.}

В основу алгоритму відбору атрибуту на $j$-му кроці рекурсії покладено такий інформаційний показник:

$$
\operatorname{Gain}\left(A_{i}\right)=\operatorname{Info}\left(D_{j}\right)-\operatorname{Info} o_{A_{i}}\left(D_{j}\right) .
$$


Тут

$$
\operatorname{Info}\left(D_{j}\right)=-\sum_{k=1}^{K} p_{k}^{j} \log _{2}\left(p_{k}^{j}\right)
$$

— інформація, потрібна для класифікації набору $A_{1}, \ldots, A_{p}$ в $D_{j}$,

$$
\operatorname{Info}_{A_{i}}\left(D_{j}\right)=\sum_{l=1}^{K_{i}} \frac{\#\left(D_{j}^{l}\right)}{\#\left(D_{j}\right)} \operatorname{Info}\left(D_{l}\right)
$$

- інформація, потрібна для класифікації $A_{1}, \ldots, A_{p}$ в $D_{j}$ після поділу $D_{j}$ на підмножини $D_{j}^{l}$ відповідно до значень атрибуту $A_{j}$.

У формулі (2) ймовірність того, що довільний набір з $D$ належить множині $C_{k, D_{i}}$ оцінюється як $p_{k}^{j}=\frac{\#\left(C_{k, D_{j}}\right)}{\#\left(D_{j}\right)}$, де $C_{k, D_{i}}-$ множина наборів з $D_{j}$, для яких атрибут класу $C=k$. Тут \#(•) — кількість елементів в множині.

У формулі (3)

$$
\frac{\#\left(D_{j}^{l}\right)}{\#\left(D_{j}\right)}
$$

- оцінка ймовірності того, що довільний набір з Dj належить множині $D_{j}^{l}$, де $D_{j}^{l}$ - множина наборів з $D_{i}$, для яких атрибут $A_{i}=a_{i}^{l}$. Тут атрибут $A_{i} \in\left\{a_{i}^{1}, a_{i}^{2}, \ldots, a_{i}^{K_{i}}\right\}$.

Отже, Gain( $\left.A_{j}\right)$ оцінює зменшення інформації, необхідної для класифікації довільного набору даних в $D_{j}$, за рахунок відомого значення атрибуту $A_{\text {. }}$. Таким чином, $з$ наявних атрибутів на кожному вузлі дерева рішень для умови поділу слід відбирати атрибут $A_{i}$ з найбільшим значенням $\operatorname{Gain}\left(A_{i}\right)$.

\begin{tabular}{|c|c|c|c|}
\hline $\begin{array}{c}\text { Позначення } \\
\text { атрибута }\end{array}$ & Повна назва атрибута & $\begin{array}{c}\text { Позначення } \\
\text { атрибута }\end{array}$ & Повна назва атрибута \\
\hline A1 (obstr) & акушери-гінекологи & A17 (emrgn) & $\begin{array}{l}\text { надання помилкової медичної до- } \\
\text { помоги на етапі екстреної медичної } \\
\text { допомоги }\end{array}$ \\
\hline A2 (ansth) & анестезіологи-реаніматологи & A18 (admis) & $\begin{array}{l}\text { надання помилкової медичної допо- } \\
\text { моги на етапі приймального відді- } \\
\text { лення }\end{array}$ \\
\hline A3 (surg) & хірурги & A19 (hospit) & $\begin{array}{l}\text { надання помилкової медичної допо- } \\
\text { моги на госпітальному етапі }\end{array}$ \\
\hline A4 (pdtr) & педіатри & A20 (direct) & $\begin{array}{l}\text { прямий причинно-наслідковий } \\
\text { зв’язок }\end{array}$ \\
\hline A5 (family) & сімейні лікарі & A21 (dif_dig) & труднощі діагностики \\
\hline A6 (traum) & травматологи & A22 (atipic) & $\begin{array}{l}\text { атиповий перебіг патологічного про- } \\
\text { цесу }\end{array}$ \\
\hline A7 (admsn) & лікарі приймального відділення & A23 (severe) & $\begin{array}{l}\text { негативний наслідок, зумовлений } \\
\text { тяжкістю основного захворювання чи } \\
\text { травми }\end{array}$ \\
\hline A8 (diagn) & діагностичні помилки & A24 (comorb) & наявність супутньої патології \\
\hline A9 (tactic) & лікувально-тактичні помилки & A25 (vidm) & відмова хворого від госпіталізації \\
\hline A10 (istit) & організаційні недоліки & A26 (latehsp) & $\begin{array}{l}\text { пізнє звернення за медичною допо- } \\
\text { могою }\end{array}$ \\
\hline A11 (record) & дефекти медичної документації & A27 (rapid) & $\begin{array}{l}\text { швидкий перебіг патологічного про- } \\
\text { цесу }\end{array}$ \\
\hline A12 (deont) & деонтологічні помилки & A28 (regum) & $\begin{array}{l}\text { порушення пацієнтом лікарняного } \\
\text { режиму }\end{array}$ \\
\hline A13 (unsuf_) & недостатня медична допомога & A29 (ridk) & рідкісність захворювання \\
\hline A14 (untime_) & несвоєчасна медична допомога & A30 (unskill) & $\begin{array}{l}\text { некваліфіковані дії медичного персо- } \\
\text { налу }\end{array}$ \\
\hline A15 (improp_) & неправильна медична допомога & A31 (standr) & $\begin{array}{l}\text { порушення стандартів медичної до- } \\
\text { помоги }\end{array}$ \\
\hline A16 (care_abs_) & ненадання медичної допомоги & A32 (Exitus) & летальний наслідок \\
\hline
\end{tabular}

Таблиця 1

Атрибути для індукції дерева рішень стосовно лікарів-терапевтів 
В результаті такого вибору для завершення процесу класифікації набору даних в $D_{j}$ вимагатиметься найменше інформації.

Застосування методу індукції дерев рішень для встановлення судово-медичних експертних особливостей недоліків медичної допомоги.

Для встановлення можливостей метода індукції дерев рішень 3 приводу з'ясування особливостей недоліків медичної допомоги, відібрані лише ті лікарські справи, в яких судово-медичними експертними комісіями були виявлені недоліки у наданні медичної допомоги. Всього алгоритмом було обрано і піддано відповідній обробці дані 232 таких «лікарських справ». 3 усіх 70 досліджених параметрів для кожної лікарської справи було виокремлено лише ті дані, які мають першочергове значення для належної юридичної кваліфікації відповідних професійних дій медичних працівників. Загалом інформаційний аналіз проведено з врахуванням критерію розщеплення стосовно таких 32 атрибутів (табл. 1).

Для того аби встановити наявність конкретних судово-медичних експертних особливостей дефектів медичної допомоги стосовно конкретної лікарської спеціальності, як приклад досліджені справи, де обвинувачення було висунуто проти лікарів-терапевтів.

Отже, дерево рішень було побудоване з урахуванням 7424 окремих даних, а як цільову змінну для алгоритму інтелектуальної обробки даних внесено атрибут «ther» (дефекти медичної допомоги, допущені лікарями-терапевтами).

В роботі використано реалізацію алгоритму на мові R за допомогою пакета C5.0. Побудовані дерева рішень представлені на рис. 1.

Кореневим вузлом створеного дерева, як видно 3 рис. 1, став атрибут «direct» (прямий причиннонаслідковий зв’язок), що свідчить про найтісніший інформативний зв'язок (attribute usage 100\%) між лікарською спеціальністю терапевта та наявністю або відсутністю причинності між неналежними діями лікарів-терапевтів і негативними наслідками для їхніх пацієнтів. Технологією Data Mining також встановлено сильну і середню кореляцію з такими атрибутами (рис. 1): «Exitus» - 84,9\% (летальний наслідок), «іmprop_» - 68,5\% (неправильна медична допомога), «admis» - 62,5\% (дефект медичної допомоги допущено у приймальному відділенні лікарні), «standr» - 59,9\% (судово-медичними експертними комісіями доведені порушення протоколів чи стандартів надання медичної допомоги), «comorb» — 42,7\% (об’єктивною причиною недоліку медичної допомоги стала супутня патологія), «rapid» - 37,9\% (об’єктивною причиною недоліку у наданні медичної допомоги став швидкий перебіг патологічного процесу).

Аналіз гілки «уеs» кореневого вузла «direct» свідчить, що серед усіх випадків наявності прямого причинно-наслідкового зв’язку між неналежними діями медичного працівника і шкідливими для хворого наслідками, лікарів-терапевтів серед таких медичних працівників не було $(\mathrm{n}=35, \mathrm{P}=1,0)$. Тобто, якщо лікарі-терапевти і допускають певні недоліки, які в подальшому призводять до несприятливих для пацієнтів наслідків, то судово-медичними експертними комісіями зазвичай наявність причиннонаслідкового зв’язку не підтверджується.

Аналіз гілки «по» цього кореневого вузла засвідчує, що серед усіх випадків «лікарських справ», де прямий причинно-наслідковий зв'язок між діяннями медичних працівників та негативними наслідками встановлений не був, важливе значення серед особливостей неналежного надання медичної допомоги лікарями-терапевтами посідає атрибут «Exitus» (смерть пацієнта), що констатується серед 84,9\% усіх досліджених алгоритмом випадків (n=197). Однак за відсутності причинно-наслідкових зв’язків і за умови ненастання летального для хворого результату (значення «по» атрибута «Exitus»), 37 кримінальних проваджень з 38 «лікарських справ» не стосувались лікарів-терапевтів і були відкриті проти лікарів інших фахів. Це слід розуміти так, що серед тих випадків неналежної професійної медичної діяльності, де не наступав летальний кінець, і де не було причинно-наслідкових зв’язків між діями лікарів та шкідливими наслідками, з ймовірністю 37/38 (P=0,97) не буває лікарів-терапевтів.

Подальший аналіз індукованого дерева, зокрема гілки «direct-no-Exitus-yes-improp_-yеs», демонструє значний кореляційний зв’ язок між цільовою змінною «ther» (кримінальна справа, яка була порушена проти лікарів-терапевтів) і атрибутом «іmprop_» (медична допомога була надана неправильно), що спостерігалось серед 68,5\% «лікарських справ», опрацьованих алгоритмом. У тих випадках дефектів медичної допомоги, коли настав смертельний для пацієнта кінець, i коли надана медична допомога була неправильною, в 13 випадках з 14 не було лікарів-терапевтів $(\mathrm{P}=0,93)$. Тобто летальний наслідок, який виник внаслідок неправильного надання медичної допомоги, з високою вірогідністю для лікарів-терапевтів не характерний. 


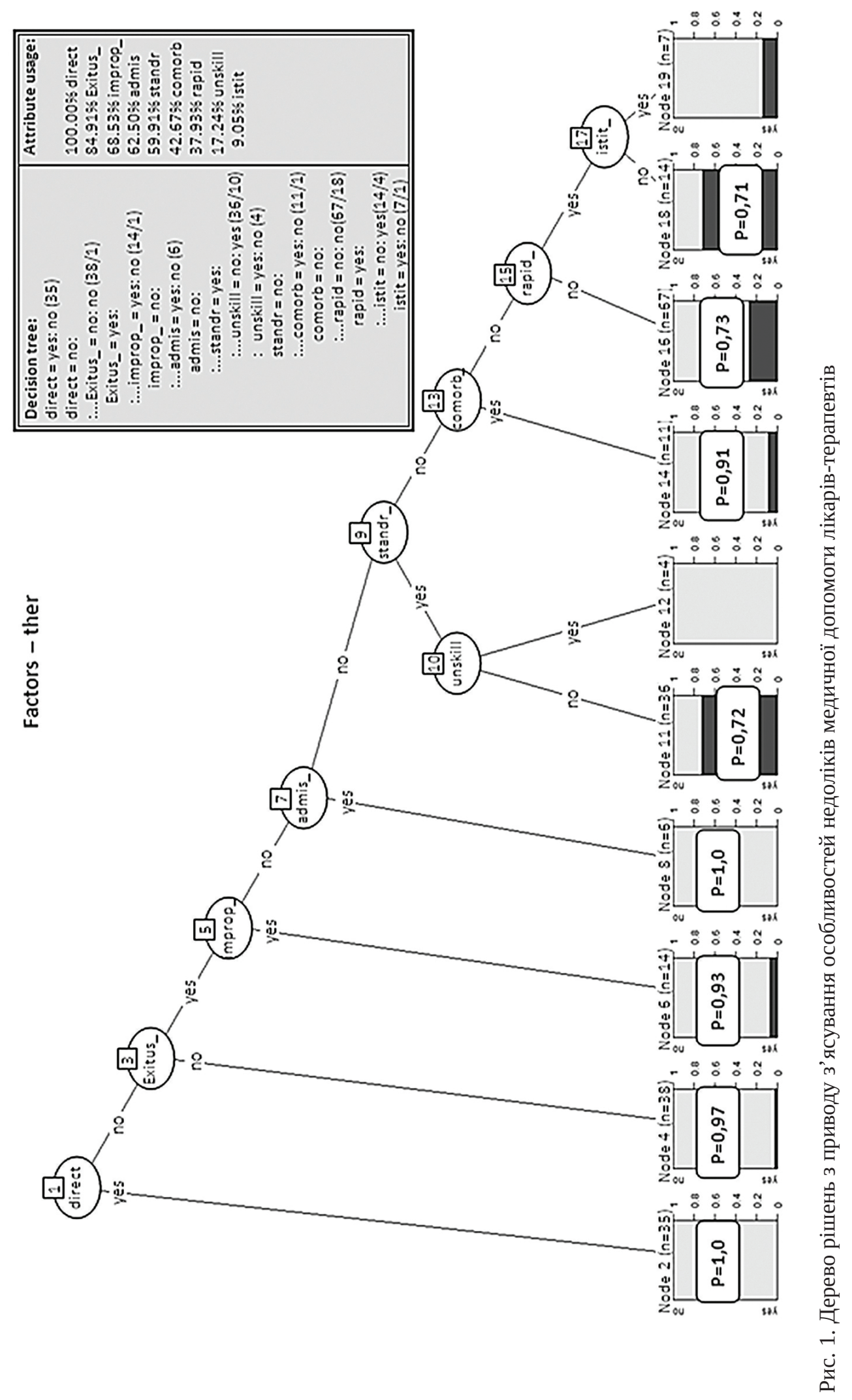


Цікавим для аналізу видається вузол індукованого дерева «standr» (рис. 1), attrribute usage якого становить 59,9\% і означає відсоток кримінальних проваджень, відкритих проти лікарів-терапевтів, які за своєю інформативністю найбільш тісно пов'язані з порушеннями у клінічних протоколах чи стандартах медичної допомоги. Порушення стандартів у наданні медичної допомоги часто супроводжуються некваліфікованими діями медичного персоналу, проте аналіз гілки «standr-yes-uskill-no» демонструє, що серед 36 випадків відсутності некваліфікованих дій медичних працівників 26 таких «лікарських справ» стосувались лікарів-терапевтів. Інакше кажучи, коли лікарі-терапевти припускаються різноманітних відхилень чи порушень з боку відповідних інструкцій, регламентуючих надання медичної допомоги, з досить високою ймовірністю (26/36, $\mathrm{P}=0,72)$ їхні дії не визнаються судово-медичними експертними комісіями як некваліфіковані.

Аналіз термінальних вузлів дерева (рис. 1) доводить, що наявність супутньої патології як однієї з об’єктивних причин недоліків у наданні медичної допомоги (атрибут «comorb») з ймовірністю $\mathrm{P}=0,91$ для лікарів-терапевтів не є характерною, оскільки таких випадків було $10(\mathrm{n}=11)$.

Більший вплив на недоліки у наданні терапевтичної допомоги має така об'єктивна причина, як швидкий перебіг патологічного стану (вузол дерева «rapid»), що тісно пов'язане з дефектами в організації медичної допомоги (атрибут «istit»). При цьому у випадках летального наслідку і швидкого перебігу патологічного процесу виникає зв'язок 3 організаційними дефектами (термінальний вузол «іstit»), відсутність яких (n=14) з ймовірністю $\mathrm{P}=0,71$ характерна для лікарів-терапевтів.

\section{Література.}

1. Завальнюк А. Х. Етично-правові аспекти лікарської діяльності в Україні : монографія / А. Х. Завальнюк, Г. Ф. Кривда, І. О. Юхимець. — Одеса : Астропринт, 2008. - 192 c.

2. Кримінальний процесуальний кодекс України : Закон, Кодекс від 13.04.2012 № 4651-VI / Верховна Рада України // Відомості Верховної Ради України. — 2013. — № 9-10, № 11-12, № 13. — ст. 88.

3. Марценюк В. П. Використання технології Data Mining із метою диференціальної діагностики коморбідних станів хронічного панкреатиту й аскаридозу на підставі даних клінічної симптоматики й ультразвукових досліджень / В. П. Марценюк, Л. С. Бабінець, Ю. В. Дроняк // Медична інформатика та інженерія. — 2017. — № 4. — С. 20-29.

\section{Висновки.}

Підсумовуючи отримані результати, що аргументовані відповідною інтелектуальною програмою обробки бази даних, можна виокремити такі судово-медичні експертні ознаки, характерні для неналежної медичної допомоги в терапевтичній практиці: відсутність прямого причинного-наслідкового зв'язку між діями (бездіяльністю) лікарів-терапевтів і шкідливими наслідками $(\mathrm{P}=1,0)$, відсутність неправильної медичної допомоги $(\mathrm{P}=0,93)$. За умови, коли лікарі-терапевти припускаються порушень діючих протоколів у наданні медичної допомоги, з ймовірністю $\mathrm{P}=0,72$ їхні дії не визнаються судово-медичними експертними комісіями як некваліфіковані. 3 високою ймовірністю $(\mathrm{P}=0,91)$ на недоліки у наданні медичної допомоги в терапії не впливає такий об'єктивний фактор, як супутня патологія. Більший вплив на якість здійснення лікувально-діагностичного процесу лікарями терапевтичного фаху має така об’єктивна причина, як швидкий перебіг патологічного стану, що інформативно (за математичним розрахунком інформаційної ентропії) тісно пов'язане з дефектами в організації медичної допомоги. Організаційні недоліки, однак, з ймовірністю $\mathrm{P}=0,71$ для лікарівтерапевтів не характерні.

Перспективи подальших досліджень полягають у з'ясуванні судово-медичних експертних особливостей дефектів медичної допомоги в різних галузях клінічної медицини шляхом індукції дерев рішень.

4. Нечипорук Д. В. Особенности технологии Data Mining / Д. В. Нечипорук // Молодой исследователь Дона. — 2017. — № 1 (4). — С. 62-65.

5. Савченко Л. М. Datamining и области его применения / Л. М. Савченко // Актуальные проблемы авиации и космонавтики. Секция Информационноэкономические системы. - 2015. - Т. 1. C. 611-613.

6. Судова медицина. Медичне законодавство : підручник у 2 кн. / М. В. Банчук. В. Ф. Москаленко, Б. В. Михайличенко [та ін.] ; за ред. акад. НАМН України, проф. В. Ф. Москаленка, проф. Б. В. Михайличенка. — Київ : Медицина, 2011. — Кн. 2 : Медичне законодавство : Правова регламентація лікарської діяльності. - 496 с.

7. Ташкинов А. А. Применение метода деревьев классификации к прогнозированию уровня развития 
моторики у больных с нарушениями двигательных функций / А. А. Ташкинов, А. В. Вильдеман, В. А. Бронников // Российский журнал биомеханики. 2008. — Т. 12, № 4 (42). — С. 84-95.

8. Франчук В. В. Судебно-медицинские особенности ненадлежащей медицинской помощи в современной Украине / В. В. Франчук // Судебно-медицинская экспертиза. - 2018. — Т. 61, № 2. - С. 48-52.

9. Martsenyuk V. P. Indirect method of exponential convergence estimation for neural network with discrete and distributed delays / V. P. Martsenyuk // Electronic Journal of Differential Equation. — 2017. — No. 246. - P. 1-12.

10. Martsenyuk V. P. On an indirect method of exponential estimation for a neural network model with discretely distributed delays / V. P. Martsenyuk // Electronic Journal of Qualitative Theory of Differential Equations. — 2017. - No. 23. - P. 1-16.

11. Martsenyuk V. P. Qualitative analysis of the antineoplastic immunity system on the basis of a decision tree / V. P. Martsenyuk, I. Y. Andrushchak, I. S. Gvozdetska // Cybernetics and Systems Analysis. - 2015. — Vol. 51, No. 3. - A013, 461-470.

\section{References.}

1. Zaval'nyuk, A. Kh, Krivda, G. F., \& Yukhimets', I. O. (2008). Etichno-pravovi aspekti likars'koi diyal'nosti v Ukraini [Ethical and legal aspects of medical activity in Ukraine]: monograph. Odesa: Astroprint. [In Ukrainian].

2. Kriminal'nii protsesual'nii kodeks Ukraini [Criminal Procedure Code of Ukraine]. (2013). Vidomosti Verhovnoyi Rady Ukrayiny (Reports of the Verkhovna Rada of Ukraine), 9-13. [In Ukrainian].

3. Martsenyuk, V. P., Babinets’, L. S., \& Dronyak, Yu. V. (2017). Vikoristannya tekhnologii Data Mining iz metoyu diferentsial'noi diagnostiki komorbidnikh staniv khronichnogo pankreatitu i askaridozu na pidstavi danikh klinichnoi simptomatiki i ul'trazvukovikh doslidzhen' [An application of Data Mining technology with aim of differential diagnostics of the comorbidic states of chronic pancreatitis and ascaridosis on the basis of data of clinical symptomatology and ultrasonic researches]. Medichna informatika ta inzheneriya (Medical informatics and ingineering), 4, 20-29. doi: 10.11603/mie.1996-1960.2017.4.8447. [In Ukrainian].
4. Nechiporuk, D. V. (2017). Osobennosti tekhnologii Data Mining [Data Mining technology features]. Molodoi issledovatel' Dona (Don's young scientist), 1(4), 62-65. [In Russian].

5. Savchenko, L. M. (2015). Datamining i oblasti ego primeneniya [Datamining and its applications]. Aktual'nye problemy aviatsii i kosmonavtiki (Modern advances of aviation and cosmonautics), 1, 611-613. [In Ukrainian].

6. Banchuk, M. V., Moskalenko, V. F., Mikhailichenko, B. V. (2011). Sudova meditsina. Medichne zakonodavstvo [Forensic Medicine. Medical Law]: textbook. Kyiv: Medicina (Medicine). [In Ukrainian].

7. Tashkinov, A. A., Vil'deman, A. V., Bronnikov, V. A. (2008). Primenenie metoda derev'ev klassifikatsii k prognozirovaniyu urovnya razvitiya motoriki u bol'nykh s narusheniyami dvigatel'nykh funktsii [Application of the mrthod of classification trees to predict the level of motility development of patients with disturbances of motor functions]. Rossiiskii zhurnal biomekhaniki (Russian journal of byomechanics), 12, 84-95. [In Russian].

8. Franchuk, V. V. (2018). Франчук B. B. Sudebnomeditsinskie osobennosti nenadlezhashchei meditsinskoi pomoshchi v sovremennoi Ukraine [The forensic medical aspects of the inappropriate medical care in the modern-day Ukraine]. Sudebno-meditsinskaya ekspertiza (Forensic medical examination), 2(61), 48-52. doi:10.17116/sudmed201861248-52. [In Russian].

9. Martsenyuk, V. P. (2017). Indirect method of exponential convergence estimation for neural network with discrete and distributed delays. Electronic Journal of Differential Equation, 2017(246), 1-12.

10. Martsenyuk, V. P. (2017). On an indirect method of exponential estimation for a neural network model with discretely distributed delays. Electronic Journal of Qualitative Theory of Differential Equations, 23, 1-16. doi: 10.14232/ejqtde.2017.1.23.

11. Martsenyuk, V. P., Andrushchak, I. Y., \& Gvozdetska I. S. (2015). Qualitative analysis of the antineoplastic immunity system on the basis of a decision tree. Cybernetics and Systems Analysis, 51(3), A013, 461470. doi: 10.1007/s10559-015-9737-6. 